\title{
Opportunity and Constraints of Livestock Feed Resources in Abol and Lare Districts of Gambella Region, Ethiopia
}

\author{
Emana Megersa Mamo ${ }^{1 *}$, Ashenafi Mengistu ${ }^{2}$ and Getahun Asebe ${ }^{3}$ \\ ${ }^{1}$ The Federal Democratic Republic Ethiopia Sugar Corporation, Ethiopia \\ ${ }^{2}$ Addis Ababa University, College of veterinary Medicine and Agriculture, Ethiopia \\ ${ }^{3}$ Gambella University, Ethiopia
}

Submission: July 5, 2017; Published: October 30, 2017

*Corresponding author: Emana Megersa Mamo, The Federal Democratic Republic Ethiopia Sugar Corporation, Ethopia, Email: emana2004@yahoo.com

\begin{abstract}
This research was done with the objective of assessing feed resources, livestock production and associated constraints. The study was done using a formal survey, focus group discussions and field visit. Purposive sampling was employed to select 90 households (HHs) having livestock. The average family size in the Abol (5.37) was significantly $(\mathrm{P}<0.05)$ lower than Lare (9.5) district. The levels of education in both districts were very low which nearly $57 \%$ of the households were without any kind of education. Trends in communal, arable and vegetation coverage were decreasing. Livestock rearing was the main means of livelihood of the population in Lare (78.7\%) than Abol (21.7\%) district. The average number of goats, sheep and chicken in Lare district were significantly $(p<0.05)$ higher than Abol district. Natural pasture was the dominant feed resources in the area. The major livestock production constraints in the study area were ranked as health, feed, flood, drought, and theft and predators. From this study it was concluded that feed shortages occurs due to dry period and flood. Consecutively, poor conservation practices, storage of crop residues and improved forages which need effective training and demonstration to improve the productivity of livestock sector.
\end{abstract}

Keywords: Natural pasture; Livestock; Household; Conservation

\section{Introduction}

Livestock production is an integral part of the farming systems in all parts of Ethiopia. The sector has a share of 12 $16 \%$ of the total Gross Domestic Product (GDP) and 30-35\% of agricultural GDP [1]. It contributes to the livelihoods of 60 $70 \%$ of the Ethiopian population. Moreover, it ensures the availability of food, creates jobs, transportation and income to the farming community, serve as a source of agricultural inputs such as draft power and organic fertilizer as a direct contribution for crop production $[1,2]$. However, their productivity is low mainly due to factors that are related to genetic makeup, poor nutrition and poor veterinary care among others. Poor nutrition and feed shortage are the root causes for the poor performance of the livestock sector in Ethiopia. In general, it is the major impediment to the development of the country's livestock sector which results in slow growth rate in growing animals, low productive and reproductive performance [3-5].

Livestock feed resources in Ethiopia are natural pasture, crop residue, improved pasture and forages, agro-industrial byproducts, other byproducts like food and vegetable refusal, of which the first two contribute the largest share [6]. Natural pastures are naturally occurring grasses, legumes, herbs, shrubs and tree foliage that are used as animal feed [4]. These natural pastures comprise the largest feed resources, the contribution of which is estimated at $80-85 \%$ in Ethiopia [7]. Grass and browse species of communal grazing lands of sub-Saharan Africa are important sources of feed for smallholder ruminant production systems [8]. Livestock grazing is the predominant form of land use in pastoral areas which receive less than $600-700 \mathrm{~mm}$ annual rainfall. Natural pastures are decreasing from time to time and gradually disappearing due to rapidly increasing human population and expansion of cropland [4]. Overgrazing might also have been the main factor for the decline in the composition and diversity of plant species over a long period of time $[9,10]$.

Gambella region is endowed with diverse species of grasses and browses [11] yet there is feed problems for livestock. Therefore, it requires a systematic documentation of 
information on the production opportunities and constraints, availability and importance of livestock feed resources of the area.

Thus, the objectives of this piece of work were:

a. To assess livestock production systems and associated constraints

b. To assess available feed resources

\section{Materials and Methods}

\section{Description of the Study Area}

The study was carried out at Abol and Lare districts of the Gambella People's Regional State (GPNRS). Abol district is one of the districts in Anuak zone having a total land area of $3,118.79 \mathrm{~km} 2$ where $20 \%$ of it is covered by forest. The total human population of the district is 10, 590 with 2595 households. The district is found at an elevation of 400 600 masl bordered on the south by Abobo and on the west by Itang districts and on the north and east by Oromia Regional State [12].

Lare district is part of the Nuer zone which covers a total land area of $685.17 \mathrm{~km} 2$ a human population size of 31,406 and 5,432 households. It is found at an elevation of 300 to 400 masl and bordering on south and east by Anuak zone, on west by Baro River which separates Jikawo and on north by Jikawo River which separates from south Sudan. The terrain in Lare consists of marshes and grass lands [12]. The study districts were an annual rainfall varying from 900 to $1,500 \mathrm{~mm}$. The absolute maximum temperature occurs in mid March and is about $450 \mathrm{C}$ and the absolute minimum temperature occurs in December and is $10.30 \mathrm{C}$ [11].

\section{Study Design}

The study involved questionnaire surveys, field visits and observation, focus group discussions and key informant interviews with the main objectives of identifyinglivestock production constraints and available feed resources.

\section{Sampling Procedures and Determination of Sample Size}

The districts were selected randomly from the low lands of Gambella from which three peasant associations (PAs) were also selected randomly from each of the districts. Those districts and PAs which have security problems were excluded. The sample size was determined according to Arsham [13] with the formula of $n=0.25 / \mathrm{SE} 2$, where $\mathrm{SE}=5.27 \%$ and at Table 1: Profile of households $(\mathrm{HH})$ by family size, age, educational background and land holding

\begin{tabular}{|c|c|c|}
\hline Variables & Abol district (mean \pm SD n=30) & Lare District (mean \pm SD,n=60) \\
\hline Age of HH (year) & $45.8 \pm 10.6$ & $41.3 \pm 14.1$ \\
\hline Family size(no) & $5.4 \pm 1.8 \mathrm{a}$ & $9.5 \pm 3.9 \mathrm{~b}$ Private land (ha) \\
\hline Age of HH (year) & $45.8 \pm 10.6$ & $41.3 \pm 14.1$ \\
\hline Male & 73.3 & 88.3 \\
\hline
\end{tabular}

confidence interval of $5 \%$. Accordingly, a total of ninety (90) households (HHs) were purposively selected, 30 from Abol and 60 from Lare distributed based on the principle of sample proportional size, were involved in the study. The sampling frame comprised only of those households with livestock.

\section{Data Collection Method}

Closed and open ended questionnaires were prepared and used for data collection through field visits, group discussions and key informant interviews. During the assessment, discussions were held with pertinent experts and secondary data were collected from the Agriculture Office of the districts. In addition to the closed and open ended questionnaires, informal discussions were held with a group of households in each of the PAs and with development agents working in the localities. In the process of the questionnaire development, due emphasis was given to the following core subjects: socio-economic characteristics of the household, livestock production and associate constraints, types of feed resources and time of availability. Enumerators were recruited and trained to administer the pretested questionnaires. The researcher was also involved in supervising the processes and the actual data collection which extended from November to December 2013.

\section{Data Management and Analysis}

The collected household data were organized, summarized and analyzed with the help of Statistical Package for the Social Sciences [14]. Descriptive statistics such as mean, percentage and standard deviation were used to present the results. Chi-square (X2) test and mean comparisons (t-test) was also employed in this study.

\section{Results}

\section{Socio-economic Characteristics of the Households}

Demographic characteristics of the households: The average family size in the Abol district was 5.37 per household with a range of 2 to 10 which was significantly $(\mathrm{P}<0.05)$ lower than Lare district having 9.5 per household with a range of 3 to 20 (Table 1) where a family consisted of the household head, wife, children and some other dependents. In both of the study districts, marriages were observed at early stage of puberty yet in Lare in addition, polygamy marriages were common that increase the average family size significantly. For instance, if the husband of one woman was died one of the close relative (like brothers) replaced him. 
Nutrition \& Food Science International Journal

\begin{tabular}{|c|c|c|}
\hline Female & 26.7 & 11.7 \\
\hline Educational back ground (\%) & & 35 \\
\hline Literate & 60 & 65 \\
\hline Illiterate & 40 & \\
\hline
\end{tabular}

$\mathrm{SD}=$ standard deviation, $\mathrm{n}=$ sample size, and means with different superscript letter in the rows was significantly $(P<0.05)$ different

Table 2: The main means of livelihood, sources of cash income and staple food for the households of the districts

\begin{tabular}{|c|c|c|}
\hline Variable & \multicolumn{2}{|c|}{ \% HH Respondents } \\
\hline Means of livelihood & Abol district(n=30) & Lare district(n=60) \\
\hline Livestock production & 21.7 & 3.7 \\
\hline Crop production & 33.3 & 3 \\
\hline Fishing & 30 & 73.4 \\
\hline Off farm activities & 15 & 18.3 \\
\hline Sale of animals and its products & Sources of cash income & 1.7 \\
\hline Sale of crops & 10 & 3.3 \\
\hline Sale of fish & 26.7 & 3.3 \\
\hline Sale of off farm activities & 18.3 & \\
\hline Sale of mixed of the above & 11.7 & \\
\hline On farm & 33.3 & \\
\hline Purchased & Sources of staple food & \\
\hline
\end{tabular}

$\mathrm{n}=$ number of households interviewed

The average age of the respondents in Abol district (45.8) were insignificantly $(\mathrm{p}<0.05)$ higher than those of Lare districts $(41.3 \pm 14.1)$. In terms of the gender proportion of the household heads, $73.3 \%$ and $88.3 \%$ of the households in Abol and Lare districts, respectively, were being headed by male respondents whereas the rest were female headed (Table 2). The percentage of the literate household heads in Abol district (60\%) was larger than in Lare district (35\%) (Table 2). This shows that in Abol most of the time the literate were highly involved in herding. In general, the levels of education in both districts were very low which nearly $57 \%$ of the households were without any kind of education (Table 2).

Table 3: Livestock ownership in the study districts.

\begin{tabular}{|c|c|c|c|c|c|c|c|c|}
\hline Districts & \multicolumn{4}{|c|}{ Livestock species(mean \pm SD and range) } \\
\hline & \multicolumn{2}{|c|}{ cattle } & \multicolumn{2}{c|}{ Goats } & \multicolumn{2}{c|}{ Sheep } & \multicolumn{2}{c|}{ chicken } \\
\hline & Mean \pm SD & Range & Mean \pm SD & Range & Mean $\pm S D$ & Range & Mean $\pm S D$ & Range \\
\hline Abol $(\mathrm{n}=30)$ & $19.7 \pm 17.4$ & $2-70$ & $5 \pm 7.3^{\mathrm{a}}$ & $0-30$ & $0.3 \pm 8.2^{\mathrm{a}}$ & $0-6$ & $3.7 \pm 8.2^{\mathrm{a}}$ & $0-40$ \\
\hline Lare $(\mathrm{n}=60)$ & $20.7 \pm 18.6$ & $3-109$ & $11.7 \pm 9.3^{\mathrm{b}}$ & $0-50$ & $10.6 \pm 11.5^{\mathrm{b}}$ & $0-60$ & $16.1 \pm 30.5^{\mathrm{b}}$ & $0-200$ \\
\hline Both $(\mathrm{n}=90)$ & $20.34 \pm 18.1$ & $2-109$ & $9.48 \pm 9.2$ & $0-50$ & $7.18 \pm 10.6$ & $0-60$ & $11.97 \pm 25.9$ & $0-200$ \\
\hline
\end{tabular}

Means with in column represent different letters $(a \& b)$ are significantly different $(p<0.05) S D=$ standard deviation, $n=$ number of household interviewed

Means of livelihood, labour divisions, sources of cash income and staple food: Livestock rearing (78.7\%) was the main means of livelihood of the population in the Lare district who are characterized as agro-pastoralists. The majority of the Nuer community derive their living from livestock
Private land holding and trends in communal grazing, arable and vegetation coverage for the past decade: On average, respondents in Abol own larger private land (1.85ha) as compared to those in Lare (1.60ha) (Table 2). Trends in communal grazing land in both districts were decreased for the past decade. The main reasons for decreasing trends of communal grazing lands were large influx of people from other areas, increasing the population pressure, investments and new enclosure for afforestation. Additionally, arable land and vegetation coverage were decreased because of investments. Moreover, arable lands were decreased in Lare district as a result of flooding. 
for doing most of the activities inside and outside the home. Male children were taking care of the livestock where as females were helping their mothers. The adult participate in crop cultivation, construction of house and fence, fishing, defending enemy and livestock herding in distance place.

The main sources of staple food for the families of both districts were own farm, purchased and largely both own farm and purchased (Table 3). These staple foods were maize, sorghum, fish, some wild edible vegetable and fruit (such as 'Neti', 'Wor,' 'Weke' and pumpkin leaves in the form of stew /'Wet') and livestock products. Maize and fish were the primary source of food for both districts yet during drought time/flooding problem, the households in the study districts were forced to eat fruits and leaves of some wild plants because of loss of their livestock and the shortage or absence of grains in the market for purchasing. Because of the increase in human population and the inadequacy of livestock production to fully support the needs of the communities in the study districts crop cultivation is practiced in both districts with integration of livestock. Almost the entire sampled households replied that they are engaged in livestock rearing, crop production and fishing. However, none of them produces beyond a subsistence level.

As shown in (Table 3), the main sources of income in Abol district was primarily the sale of crops(26.7\%), fish(18.3\%) and other off-farm activities(11.7\%) while in Lare district from Table 4: Reported relative use of livestock for household purposes

\begin{tabular}{|c|c|c|}
\hline Importance of livestock & Abol district(n=30) & Lare district(n=60) \\
\hline Food(meat, milk \&egg) & 100 & 100 \\
\hline Income sources \&saving & 96.7 & 100 \\
\hline Crop cultivation/ploughing & 46.7 & 0 \\
\hline Wedding gift & 53.3 & 100 \\
\hline Status(wealth indicator) & 96.7 & 100 \\
\hline
\end{tabular}

$\mathrm{n}=$ number of households interviewed

Table 5: Livestock production constraints in the study districts as ranked by household during focus group discussion.

\begin{tabular}{|c|c|c|c|c|c|}
\hline Districts & \multicolumn{4}{|c|}{ Constraints } \\
\hline & Feed shortage & Water shortage & Theft and predators & Drought & Health \\
\hline Abol & $2^{\text {nd }}$ & No & $5^{\text {th }}$ & $3^{\text {rd }}$ & $4^{\text {st }}$ \\
\hline Lare & $2^{\text {nd }}$ & No & $5^{\text {th }}$ & $4^{\text {th }}$ & $1^{\text {st }}$ \\
\hline
\end{tabular}

Importance of livestock in the study area: Livestock are the main assets of the households in the study area especially in Lare district upon which the livelihood of the community depends. They are used as a source of food (milk, meat and egg), social functions (status and bride payment), as a means of saving, income source, and risk minimization. In Lare district, the entire households interviewed agreed upon the use of their livestock as sources of food, wedding gift, indicators of status, sources of income and saving account but in Abol district the percentages of these functions different because of different community found in the sale of livestock and livestock products(73.4\%) which was followed by the sale of crops(18.3\%), off farm activities (3.3\%) and fishing (1.7\%) indicating that the contribution of animal products to the cash income of the household was higher in Lare district. Increasing the productivity of animals would have a significant effect on improving the livelihood of the community. Wood and wood products (like house and fence construction, roofing, charcoal and fire wood) selling was also becoming an important means of earning income to some extent for few of the households living nearby the towns as off farm activities.

\section{Livestock Composition, Importance, Constraints and their Housing}

Livestock compositions: In both districts of the study area there was a large variation among the herders in terms of their livestock ownership. Cattle were the most important species followed by goats, sheep and chicken. These species of animal predominated livestock species in all the localities included in the assessment. They use them like other parts of the country; except oxen in which case they are not used for cultivation. The average numbers of cattle, goats, sheep and chicken were 20.7, 11.7, 10.6 and 16.1 per household, respectively, in Lare as compared to 19.7, 5, 0.3 and 3.7, respectively in Abol (Table 4). The average numbers of goats, sheep and chicken in Lare district were significantly $(\mathrm{p}<0.05)$ higher than those of Abol district (Table 4).

it (Table 5). In general in the study districts the households do not slaughter animals for home consumption in normal times but consume animal products such as milk, meat and eggs and byproduct. However, they slaughter animals during cultural ceremonies such as wedding and if the household is rich more casual slaughters can be observed; and few of them use died livestock as source of meat for home consumption. The number of cattle they owned decides the status of individuals in the community. Households with 100 and more heads of cattle are considered rich. In addition, bride payment was one of the traditions in both districts of 
indigenous community which cattle play the major role. For instance, in Nuer community if one wants to marry the girl he must pay twenty five cattle for the girl parents. Cultivation of crops with oxen was a recently introduced activity by different settlers but no one of the indigenous people uses oxen as a source of draught power. With regard to the role of animals as a means of saving, income source, and risk minimization cattle were used in the societies as bank saving account and small ruminants as liquid assets. Livestock are kept for sale during emergency and at the time of crop failure. In the area the farmers did not use farmyard manure to improve soil fertility instead used to smoke for protecting livestock from disturbance and bite of flies.

Table 6: Responses of households by percentages on types of housing constructed for livestock in districts

\begin{tabular}{|c|c|}
\hline Types of shade & \% of households $(\mathbf{n}=\mathbf{9 0})$ \\
\hline Closed shade & 15.6 \\
\hline Open shade & 28.9 \\
\hline Simple barn & 12.2 \\
\hline Tethering & 43.3 \\
\hline
\end{tabular}

Livestock production constraints: Results of the focus group discussions and key informant interviews on livestock production constraints are summarized (Table 6). Animal health related constraints were ranked to be the most important followed by shortage of feed in both of the districts. In Lare district flood was ranked third in which it covered all the area grazed by livestock during the rainy season aggravates feed shortage and disease problems. In Abol district, on the other hand, drought was ranked as the third followed by flood. In both districts there were no reports of water shortage except the quality of water which deteriorates during the rainy seasons because of the occurrence of flood. In addition, theft and attack by predators were ranked as the 5th in where the Murlee tribes from south Sudan were accused of thefts and predators (lion \& hyena) reportedly cause livestock losses. Animal diseases such as trypanosomiasis, pasteurllosis, contagious, caprineplearopnemonia (CCPP), foot and mouth disease (FMD), black leg and anthrax; parasites such as ticks and inadequacy of facilities were among the reported animal health problems. In addition, animal health centers were not easily accessible to most people in the districts making them walk two to three hours to get veterinary services. As a result, most of people use traditional healers to treat their sick animals.

Types of livestock house: Housing was the most important requirement to protect livestock from extreme hot weather, attack by predators and theft. In the study area, closed shade(15.6\%) was constructed most of the time for goats and sheep but for cattle sometimes they construct open shade(28.9\%) and simple barn(12.2\%) or tethering in open area/ under bigtrees(43.3\%) around the homesteads (Table 7). Due to the susceptibility of small ruminants to theft and predators, farmers tend to construct closed type of house for this group of animals. Tethering cattle, primarily those that require special attention, in and around the homesteads is a common practice. For instance, if one wants to count his/her cattle instead only he/she counts tethering material.

Table 7: Feed resources and their time of availability listed in their rank of importance

\begin{tabular}{|c|c|c|}
\hline $\begin{array}{c}\text { Feed } \\
\text { resources }\end{array}$ & $\begin{array}{c}\text { Availability by } \\
\text { percentage }\end{array}$ & Time of Availability \\
\hline Grasses & 100 & May to October \\
\hline Browse species & 63.3 & Year round \\
\hline Crop residues & 32.2 & September \\
\hline Others('Atela') & 3.3 & $\begin{array}{c}\text { At the time "Atela" is } \\
\text { available }\end{array}$ \\
\hline
\end{tabular}

\section{Available Feed Resources and their Distribution} Overtime

As ranked during focus group discussions the predominant livestock feed resources in the area are grasses followed by browse plants. Grasses are the most preferred feed resources by cattle in the area where as browses are the main feeds of goats and mostly used for cattle during dry period. These browse plants in addition to feed for livestock and food for human consumption they are also used for construction purpose, fire wood and traditional medicines. Crop residues (stovers of maize and sorghum) were also in the list of important feed resources in those areas which practice crop cultivation. Other important feed resources include 'Atela' the by product from brewing local beverages. However, in the area there was no practice of conserving feed resources (hay and silages), planting of improved forages, using of agro by-products and storing of crop residues.

Seasonal variation in feed quality and quantity is one of the most important constraints that limit livestock productivity in the area. For instance, in the area feed shortage was occurring due to flood and dry period. Flooding is the severely devastating problem in Lare and river bank of Abol district that occurs annually (Figure 2). Plenty of grasses are available for about six months starting from May to December. The browse plants were evergreen and available year round but mainly browsed in the dry season at the time when the growth of grasses and other herbaceous plants is severely affected. Feeds were abundant during the rainy season in the district except in areas affected by flood.

\section{Discussion}

This section of the thesis attempts to discuss the observed results following the sequence in the previous section as follows:

\section{Socio-economic Characteristics of the Households}

The survey results revealed that the average family size in the study districts was $8.12 \pm 3.86$ with the range of 
2 to 20 which was lower than Borana pastoralists (13.5) reported by Alemayehu [7] and Alaba district of SNNP (8.52 and ranging from 2 to 25) by Yeshetila [15]. However, this result was higher than reported for the Kereyu district (6.17) by Abule [16] and south Omo zone (7.1) by Terefe et al. [17]. This may be ascribed to the presence of polygamy in the districts of the current study as opposed to the Omo zone [17]. The average age of the respondents in both districts were $42.79 \pm 1.31$ with the range of 20 to 75 which was similar to Alaba district households reported by Yeshitela [15] and less than the average age reported by Terefe et al. [17] at south Omo zone The majority of the household headed in the study districts were male as has been reported elsewhere $[15,17]$.

The low level of educational status in the districts may exert adverse impact on technology transfer and hamper the productivity of the interventions being made in the district. Average literacy level of the respondents in both the study districts(43.3\%) was much better than south Omo zone which was $98.1 \%$ illiterates according to Terefe et al. [17] but less literates than Alaba district in which the figure reported was 58.5\% [15]. Most of the children of the communities in the current study were going to school which is different from the situation in south Omo zone (Terefe et al.,2010) [17] in which chance to go to school depended on family size for labor division.

The average land holding of the overall study sites per household was less than the value reported by Yeshitila [15] in Alaba district (2.22ha) and land holding in high land ranges from 0.5 to 4 ha [18]. Trends in communal grazing, arable land and vegetation coverage were decreasing for the past decades. This finding was similar with other findings reported by Yeshitila [15] in Alaba district and Tefera et al. [17] in south Omo zone in which communal grazing lands decreasing because of cultivation and sharing among households near the area, which was not the case in the study districts in which communal landing was decreasing because of investments and enclosure by government as forest area.

The activities carried out by women in the study district were similar with many parts of the pastoralists reported by different authors like Terefe et al. [17] at south Omo zone and by Adugna and Aster [5] at Borana zone in which many of the activities such as home duties, care of children, care of calf, diseased animals and small ruminant around the home. The youngsters and adults also have the responsibility of defending the tribes and villagers from the attacks by other tribes or groups and this is similar to the case in Afar and Kereyu [19] and the Borana pastoralists [20].

The sale of animals and animal products constitute the main sources of cash income in Lare agro- pastoral district. Similarly a previous study conducted by Desta and Coppock [21] showed that sales of livestock and dairy products constitute the main source of cash income in the North-Central Borana plateau. Fishing, occasional sale of crops and sale of wood and wood products play a secondary role as sources of cash income in the area similar to Liben zone of Somalia and Borana zone of Oromia by Adugna and Aster (2007) [5] except fishing. As in the case of Nuer agro- pastoralists and this dependence on livestock as the main source of income is well documented in other pastoral areas of Ethiopia by Alemayehu [7] and Abule [16].

In general, there was no difference among the households in the study districts in what they eat during good, pre-drought or drought times and this is in agreement with the practice of Borana pastoralists [22]. In study districts people were enforced to eat wild plants during drought time which is in agreement with the report of Hailemariam et al. [11] that states in Nuer community during drought year, seasonal movement was practiced, during the rainy season they stay in one place for long period of time and then they move to upland areas in search of pasture and return to the bank of the river during the dry season in search of fish, forest fruits, cultivation flood recession crops, and green pasture and water for livestock. Similarly in Anuak when food is short in the dry season peoples compelled to go as a group to the escarpment (where Mejenger live) in search of wild roots during the drought season.

\section{Livestock Composition, Importance and Constraints}

Majority of the household in the study districts keep more than one species of animal mainly, cattle, goat, sheep and chicken where advantages can be taken of the various adaptation strategies of the different animal species to diseases, feed shortage, drought and the diversity of the output to be obtained from the animals and this is in agreement with the reports from the other pastoral areas of Ethiopia and the East African countries [23]. The Nuer communities have a long experience and a very strong attachment to cattle rearing similar with Borana Oromo reported by Adugna and Aster [5] whereas Anuak community were not.

Similar to Getachew et al. [24] livestock have multiple roles in the smallholder farming systems in the area. For instance, they used as food, for income generations, saving accounts, social functions, power of cultivations and their manure as fertilizers. However, in the study area what makes differ in that the indigenous tribes do not use livestock for power of cultivation/ploughing, threshing, modes of transport and their manures were not used for soil fertility instead used for smoking to protect flies compared to other part of the country Yeshitila [15] and Gryseels and Goe [25].

Constraints of livestock in the study area were ranked animal health and feeds as the main problem during focus group discussions which disagree with report of Adugna 
and Aster [5] in Borana pasoralists where drought and feed shortages ranked followed by health. Health problem include, diseases, parasites, flies disturbance and others which were more or less similar to the constraints faced by animals of different pastoral areas in Ethiopia [26]. Feed shortages were faced due to dry period and flood in the area which agrees with the report of Hailemariam et al. [11]. The prolonged dry season and flood are the causes for high mortality rate which is similar report in Borana pastoralists due to drought [5]. Flood is the most common natural disaster in the area that affects agricultural sector, human health, infrastructure and settlement; and the over flow of big rivers displaced thousands of people and destroyed property which is consistence with report of Hailemariam et al. [11].

\section{Available Feed Resources and their Distribution Overtime}

Feed resources available in the area were natural pastures which includes grasses and browse species. These feed resources were highly depending up on climate or seasons that agree with report of Mohamed-Saleem and Abate [27]. Seasonal variations in feed quality and quantity is the main limitation to animal production and cause fluctuation in productivity throughout the year, particularly in the dry and flooding seasons during which feed is scant and poor in nutritive value which consistence with the report of Alemayehu and Sissay [6].

The use of browse plants in addition to feeds and food they have been used for different purposes which agrees with report of Gemedo et al. [28] and Teshome et al. [29]. Being perennial plants, fodder plants are not susceptible to sudden climatic changes and continue to maintain their green leaves longer into the dry season and known to produce high quality fodder even during drought years when grasses and other annual forages are dry and long gone due to their deep root systems which agrees with report of Coppock [22] and Eshetu [30]. However, no farmers climb up fodder plants to lop down for their livestock except very few farmers when they face critical problems similar with the report of Yeshitila [15].

In highland of the country, animals will depend more on crop residues during the dry season [31] and Shitahun (2009) in Bure woreda Amahara region yet in the study district there was no practice of storing crop residues, conserving any feed resources in the form of hay and silages and planting of improved forages for dry period. So, as the coping mechanism during dry seasons they only move their livestock around the river bank where natural pasture available [32].

In the study area continuous grazing systems were used yet low stocking rate observed during rainy seasons in which the natural pastures were underutilized. In other region of the country in addition to dry period or may be flood, feed shortages occurs due to increasing human, livestock population and increasing of arable land. These indicate shrinkages of grazing land which was reported by Adugna and Aster [5].

\section{Conclusion}

Livestock and livestock products, fish, crops and some wild leaves and fruits were the staple food of the households contacted. The main constraints of livestock production identified in the areas were health, feed shortage, flood, drought, theft and predators. Moreover, inadequate facilities for veterinary services were also reported as one of the livestock production constraints in the area subsequently leading the producers to use traditional healers for the treatment of their sick animals.

The region as whole is endowed with diverse species of grasses and browse plants covering a vast area of land. During the main rainy season, availability of feed is not a problem in the area. However, feed shortage is prevalent during the dry period and times of flood affecting livestock production and productivity. At times of feed shortage, no practice of supplementing livestock by conserving feed resources (hay and silage) or improved forages or crop residues was observed. However, they move livestock around the river bank during dry period and flat areas during flooding.

\section{Acknowledgment}

The authors are highly indebted to thank Dr. Diriba Geleti, Dr. Ermias T/tsedik, Bizalew Gelayenew, Legesu Girshe, and Angassa Tesfaye for their valuable comments. They would like to extend their thanks to Gambella ATVET College and Addis Ababa University for providing finance.

Finally the authors would like to thank staff members of Lare and Abol Woreda Agriculture and Rural Development Office and those farmers participated in this study for their hospitality and genuine approach throughout the study period without whom, complete data collection would have been impossible.

\section{References}

1. Ayele S, Assegid W, Jabbar MA, Ahmed MM, Belachew H (2002) Livestock marketing in Ethiopia. A review of structure, performance and development initiatives. Socio-economics and Policy Research Working Paper 52, ILRI, Nairobi, Kenya.

2. Zinash S, Tegegne A (2000) Challenges and opportunities for livestock development in the highlands of Ethiopia. In: Tulachan PM, et al. (Eds), Contribution of livestock to mountain livelihoods: Research and development Issues. Proceedings of the International symposium on livestock in mountain/highland production systems: Research and development challenges into the next millennium, Pokhara, Nepal pp. 95-102.

3. Assefa A (2005) Farm management in mixed crop livestock systems in the Northern Highlands of Ethiopia. PhD Thesis, Wageningen Agricultural University, Wageningen, the Netherlands. 
4. Adugna T (2007) Feed Resources for Producing Export Quality Meat and Livestok in Ethiopia. Ethiopia Sanitary and Phytosanitary Standards and Livestock and Meat Marketing Program (SPS-LMM) managed by Texas Agricultural Experiment Station (TAES) of Texas A \& M University System.

5. Adugna T, Aster A (2007) Livestock production in pastoral and agropastoral Production systems of southern Ethiopia. Livestock Research in Rural Development 19(12): 1-12.

6. Alemayehu M, Sissay A (2003) Integrated Livestock Development Project (ILDP). Livestock Feed Resources Survey, North Gondar, Ethiopia 75-82.

7. Alemayehu M (1998) The Borana and the 1991-92 drought: A rangeland and livestock resource study. Institute of Sustainable Development, Addis Ababa, Ethiopia pp 102-110.

8. Dicko MS, Sikena LK (1991) Fodder trees and shrubs in range and farming systems in dry tropical Africa. In: Speedy A, et al. (Eds.) Legume Trees and other Fodder Trees as Protein Sources for Livestock. FAO, Rome, Italy pp 27-41.

9. Alemayehu M (2006) In: Range Management for East Africa: Concepts and Practices, Sponsored by RPSUD and Printed by AAU Printed Press, Addis Ababa, Ethiopia.

10. Amaha K (2006) Characterization of rangeland resources and dynamics of the pastoral production system in the Somali region of Eastern Ethiopia. Ph.D, Thesis, University of the Free State, Bloemfontein South Africa pp 417.

11. Hailemariam B, Mulugeta TS, Ali J, Galua K, Riek W, et al. (2011) Action plan of adaptation to climatic change. Gambella, Ethiopia.

12. CSA (2007) Agricultural sample survey. Livestock and Livestock characteristics, Central Statistical Authority (CSA) Bulletin 338(II), CSA, Addis Ababa pp 123.

13. Arsham H (2007) Sample Size Determination. Merrick School of Business University of Baltimore, Charles at Mount Royal, Baltimore, Maryland, 21201, USA.

14. SPSS (2003) (Version 16) Statistical procedures for social sciences (SPSS) INC, Chicago, USA.

15. Yeshitila AM (2008) Assessment of Livestock Feed Resources Utilization in Alaba Woreda, Southern Ethiopia. M.sc. Thesis, Haramaya University, Ethiopia.

16. Abule E (2003) Rangeland evaluation in relation to pastoralists perceptions in the Middle Awash Valley of Ethiopia. A PhD thesis Presented to the University of the Free State, Bloemfontein, South Africa pp 297.

17. Terefe A, Ebro A, Zewedu T (2010) Livestock-rangeland management practices and community perceptions towards rangeland degradation in South Omo zone of Southern Ethiopia. Livestock Research for Rural Development 22(1).

18. Gryseels G, Anderson FM (1983) Research on farm and livestock productivity in the central Ethiopian highlands: Initial results, 19771978. ILCA Research Report No. 4, ILCA, Addis Ababa, Ethiopia pp. 52.
19. Abule E, Snyman HA, Smit GN (2005) Comparisons of pastoralists' perceptions about rangeland resource utilization in the Middle Awash Valley of Ethiopia. J Env Manage 75(1): 21-35.

20. Solomon T (2003) Rangelands evaluation and perceptions of the pastoralists in the Borana Zone of Southern Ethiopia. PhD thesis, University of the Free State, Bloemfontein, South Africa, pp 329.

21. Desta S, Coppock DL (2004) Pastoralism under pressure: Tracking system change in southern Ethiopia. Human Ecology 32(4): 465-486.

22. Coppock DL (1994) The Borana plateau of southern Ethiopia: Synthesis of pastoral Research development and change 1980-1991. International Livestock Center for Africa (ILCA), Addis Ababa, Ethiopia.

23. Ndikumana J, Stuth JW, Kamadi R, Kamadi S, Ossiya R, et al. (2001) Copping mechanisms and their efficacy in disaster-prone pastoral systems of the greater horn of Africa: effects of the 1995-97 droughts and the 1997-98 El- nino and the responses of pastoralists and livestock pp. 106

24. Getachew A, Haile B, Werkneh N, Gezahegn A (1993) A survey of farming systems of vertisol areas of the Ethiopian highlands. In: Tekalign Mamo, et al. (eds.) Improved management of vertisols for sustainable crop-livestock production in the Ethiopian highlands. Synthesis report 1986-92. Technical committee of the joint vertisol project, Addis Ababa, Ethiopia.

25. Gryseels G. Goe MR (1984) Energy flows on smallholder farms in the Ethiopian highlands. International Livestock Centre for Africa (ILCA), Bulettin 17: 2-9.

26. Beruk Y (2003) Drought and Famine in the pastoral areas of Ethiopia. Proceedings of Conference on Pastoral Development in Ethiopia. Addis Ababa, Ethiopia, Pastoral Forum Ethiopia pp. 156-189.

27. Mohamed-Saleem MA, Abate T (1995) Feed Improvement to Support Intensification of Ruminant Production Systems in the Ethiopian Highlands. In: Proceedings of the $3^{\text {rd }}$ National Conference of the Ethiopian Society of Animal Production, Addis Ababa, Ethiopia pp. 27-29.

28. Gemedo-Dalle T, Maass BL, Isselstein J (2006) Rangeland condition and trend in the semi arid Borana lowlands, southern Oromia, Ethiopia. Afr JR and Forage Sci 23: 49-58.

29. Teshome A, Abule E, Lisanework N (2012) Evaluation of woody vegetation in the rangeland of Southeast Ethiopia. International Research Journal of Agricultural Science and Soil Science 2(3): 113126.

30. Eshete G (2002) An assessment of feed resources, their management and impact on Livestock productivity in the Ginchi watershed area. MSc Thesis, Alemaya University pp. 171.

31. FAO (2001) Grassland Resource Assessment for Pastoral Systems. Food and Agriculture Organization (FAO) Plant Production and Protection 162: 150 .

32. Chepape RM, Mbatha KR, Luseba D (2011) Local use and knowledge validation of fodder trees and shrubs browsed by livestock in Bushbuckridge area, South Africa. Tshwane University of Technology Private Bag X680, Pretoria 0001, South Africa. 


\section{Your next submission with Juniper Publishers will reach you the below assets}

- Quality Editorial service

- Swift Peer Review

- Reprints availability

- E-prints Service

- Manuscript Podcast for convenient understanding

- Global attainment for your research

- Manuscript accessibility in different formats ( Pdf, E-pub, Full Text, Audio)

- Unceasing customer service

Track the below URL for one-step submission https://juniperpublishers.com/online-submission.php 